\title{
24
}

\section{Where we PART from NSM: Understanding Warlpiri yangka and the Warlpiri expression of part-hood}

David Nash and David P. Wilkins

\section{Introduction}

As Wierzbicka and Goddard (2018: 31) (W\&G) observe, 'NSM researchers have long maintained that PART(s) is a universal semantic prime, i.e. an indefinable meaning expressible by words or phrases in all human languages'. In fact, 'be a part of' was among the original list of fourteen semantic primes published in Wierzbicka's seminal work Semantic Primitives (1972), and it remains among the current list of 65 primes as a 'relational substantive' represented as PART HAVE PARTS. NSM (Natural Semantic Metalanguage) has a strong position that all conceptual semantic primes of the lingua mentalis must have a corresponding lexical exponent in every natural language. If there were a natural language where PART was not one of the senses of at least one word, morpheme or phrase of the language, then PART would need to be removed from the set of universal semantic primes. Alternatively, NSM would need to allow that some conceptual primes do not have basic lexical expression in all languages, but are still part of the lingua mentalis. 
W\&G's search for lexification in the Australian language Warlpiri of the concept PART has led them to the controversial conclusion that it is one of the senses of the non-spatial (evocative/recognitional) demonstrative yangka 'that one, you know the one, the one in question', the most common form in the Warlpiri corpus. W\&G started from the English translations of Warlpiri examples relating to body parts in resources produced by the Warlpiri Dictionary project. They believed they could uncover the Warlpiri exponent of PART by matching the English translations-particularly those that included the word 'part' - with the Warlpiri originals. We present our objections to their method and analysis, situated in a discussion of how yangka is used in vernacular definitions in the Warlpiri Dictionary, the meaning of yangka and how Warlpiri does express the concept PART.

W\&G's general point is this:

We seek to interrogate the material included in the Warlpiri Dictionary (both Warlpiri sentences and their English translations) to make the case that Warlpiri speakers can and do talk about 'parts of the body'. (W\&G 2018: 32)

We agree: it hardly needs stating that Warlpiri speakers can and do talk about parts of the body. Our divergent view is that this obtains without the language having a word-for-word equivalent of 'part of someone's body', and that the meaning PART is not expressed by a Warlpiri lexeme. We further hold that yangka is basically monosemous, and that the cooperative interactional expectation encoded in its meaning licenses context-dependent pragmatic inferences that convey all manner of variously translatable concepts, of which PART is just one.

W\&G (2018: 32-37) provide the background to the treatment of the concept PART within NSM studies, including previous disagreement concerning Warlpiri (Nash 2014). It is fair to state, however, that their and our joint inquiry is of wider import and does not depend on particulars of the NSM approach. ${ }^{1}$

1 At least since the publication of her seminal Semantic Primitives in 1972, Anna Wierzbicka has been indefatigable in the development and promulgation of what has become known as the NSM approach to semantics. We each recall fondly our encounter with Anna in her semantics classes when we were students at ANU, in 1974 and 1978 respectively, and share her interest in comparative semantics. Anyone who knows Anna knows she is up for an argument and would rather have people engage critically and seriously with NSM rather than ignore it. We choose to honour her and her achievements through just such a critical engagement. 


\section{Methodological flaws in W\&G's approach}

As already noted, W\&G's study is based on a correlation they noticed in the Warlpiri Dictionary between illustrative Warlpiri sentences about body parts (especially the occurrence of 'part' in their English free translation) and the word yangka. (W\&G apparently did not study the other Warlpiri sentences whose English free translation also contains 'part'.) Note that, in general, the English translations were not provided by the Warlpiri speakers, so 'part' was introduced by native English speakers in their best effort translation of the sense of a Warlpiri example, not as an attempt to reflect Warlpiri semantics.

\subsection{Problems with purported examples of 'part' sense of yangka}

Consider (1), W\&G's (2018: 12) prime example of the supposed PART sense of yangka: ${ }^{2}$

(1) Kantumi, ngula kuyu yangka marlu. Kantumi manu yardipi hip that animal part kangaroo hip or hip yi-ka-rlipa ngarri-rni

AUX.COMP-PRS-IPL.INCL.SBJ call-NPST

'Kantumi is what we call that part of the kangaroo which is its hip.'

(W\&G’s glosses)

This example and free translation has been taken from the dictionary entry for yardipi 'hip', with interlinear supplied by W\&G. The dictionary took the illustration lightly edited from Hale's (1966-67: 0215) original transcription shown in (2) (and note our closer translation). The speaker uses equivalents of the word he is explaining: ${ }^{3}$

2 Abbreviations: 1 first person, 12 first person inclusive, 2 second person, 3 third person, AUx auxiliary, COMP complementiser, DU dual, ERG ergative, EVOC evocative, INCL inclusive, LOC locative, NOMIC nomic, NPST non-past, OBJ object, PL plural, POSS possessive, PRS present, REL relative, SBJ subject, TOP topic.

3 See Appendix 24.1 for source and context. 
(2) Kantumu, kantumu ngula kuyu yangka marlu. Wawirri. rump rump that animal/meat Evoc kangaroo kangaroo Kantumi manu yardipi yi-ka-rlipa ngarri-rni rump or hip AUX.COMP-PRS-IPL.INCL.SBJ call-NPST Kantumu, kantumu that is [used for] game animals, say, kangaroos.

'Kangaroo. We call it kantumu ('rump') or yardipi ('hip').'

W\&G comment that '[c]learly, this vernacular definition does not refer to "that kangaroo" but to "part of a kangaroo" (i.e. the hip)' (2018: 42-43). But it is not clear, for two reasons: (a) kuyu yangka marlu is a prosodic and syntactic unit (as apparent in the audio recording), and semantically yangka can be construed with kuyu 'game animal, meat'; (b) if yangka is construed with marlu, it can indeed mean 'that (EVOC) kangaroo', and kuyu 'meat' could be in a part-whole apposition with marlu, so it either means 'meat of the/that kangaroo' or 'game animals, say, kangaroos' (similar to the Arrernte construction discussed by Wilkins 2000). As part of understanding this passage, it helps to realise that it appears that kantumu only applies to (game) animals and is better glossed 'hind quarter' or 'rump', and that the speaker isn't defining kantumu but rather is distinguishing it from yardipi (and yarlipiri) as used for the analogous part on humans; he apparently intuits the less-common word kantumu is new to the interviewer (Hale). One clearly needs to understand the broader context of dictionary examples (and their interpretation and unedited origin) if they are to be used as data for other analysis.

\subsection{PPJ's definitional style not allowed for}

With regard to the Warlpiri vernacular definitions of body parts that they are working with, W\&G (2018: 38) acknowledge that almost all these vernacular definitions are the work of a single indigenous Warlpiri lexicographer, the late Paddy Patrick Jangala (henceforth: PPJ)'. A key point is what to make of the expression ngulaji yangka, of which W\&G claim: (i) it is not simply a definitional formula commonly used by indigenous Warlpiri lexicographers; (ii) though used extensively in body part definitions, it is not widely used in definitions of nouns of all kinds, being largely absent from fauna and artefact definitions; and (iii) 'its use in the definitions of body-parts is sui generis, and supports the hypothesis of "part" as a distinct meaning of yangka' (2018: 49). 
One of us (Wilkins) has made a close inspection of a corpus of more than 1,500 of PPJ's vernacular definitions, which undermines the position W\&G take with respect to the significance of the sequence ngulaji yangka in PPJ's definitions. The study reveals that it is part of an opening definitional formula heavily favoured by PPJ, occurring in nearly 80 per cent of PPJ's 943 nominal definitions.

Two different (non-overlapping) corpora were taken from the total set of PPJ's vernacular definitions for the variety of Warlpiri spoken at Lajamanu. The first is a corpus of 943 vernacular definitions of Warlpiri nominals, and the second is a corpus of 581 definitions of verbs (including basic verbs, preverb-verb combinations, verbs derived from nominals, etc).

PPJ's definitions have a discernible format. To begin with, 99.5 per cent of all PPJ's vernacular definitions begin:

[Definiendum] (,) ngula $=j i \ldots$

[definiendum] $\quad($,$) that ($ discourse topic $)=$ TOP

So, almost all definitions begin with something translatable as '[Definiendum], that's ...', where the word being defined is clearly in mention function and is being treated as the topic of the definitional textlet that follows.

By far the most common word to follow ngulaji in the definitional opener is yangka. The string '[Definiendum](,) ngulaji yangka ...' opens 749 (79 per cent) of PPJ's nominal definitions and 567 (98 per cent) of PPJ's verb definitions. (Yangka is the most frequently occurring word in PPJ's corpus of vernacular definitions, occurring 3,044 times.)

Clearly, ngulaji yangka is very widely used in nominal definitions, and body part definitions with ngulaji yangka are simply among the roughly 80 per cent of PPJ's nominal definitions that contain it. It is the roughly 20 per cent of nominal definitions which don't include yangka in the opening that may need explanation.

\subsubsection{PPJ Definitions without yangka}

There are two relevant factors which are highly predictive of the nonoccurrence of yangka in the opening of PPJ's nominal definitions. 
First, PPJ's earliest definitions, particularly those from 1985, are generally briefer relative to later definitions and have relatively fewer instances of ngulaji yangka in the opening. Two body part examples are his definitions of rdaka 'hand; forepaw of bipedal' and of lampurnu 'breasts', both from October 1985.

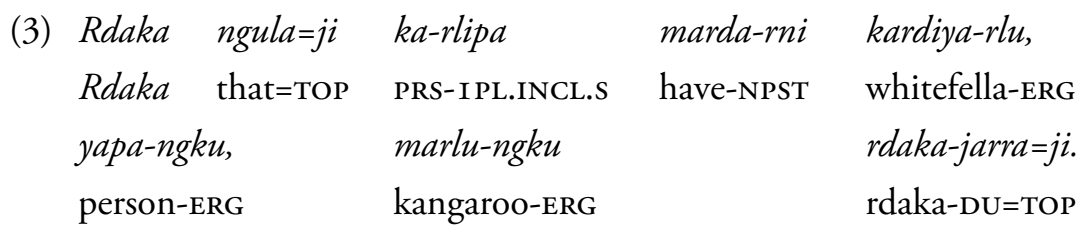

'Rdaka, that's what we all (inclusive) have-White people, Aboriginal people, kangaroos - a pair of rdaka.'

(4) Lampurnu ngula=ji ka=lu marda-rni karnta-ngku jirrama kamparru rdukurduku. Kuja-ka=lu=jana yi-nyi kurdu-ku wita-wita-ku lampurnu=ju. Ngapurlu waja.

'Lampurnu are the two things that women have in front on their chests. That they feed babies milk with breasts. (Literally, Lampurnu, that's what they have, women, two on (their) chest front. They give them to babies-that's lampurnu, it's the same as ngapurlu. $)^{4}$

Second, and consistent with W\&G's observation of fewer instances of ngulaji yangka in vernacular definitions of fauna terms (see section 2.3), is the fact that nominals that are hyponyms of a labelled superordinate are relatively more likely to have definitions in which the superordinate nominal appears immediately after ngulaji. For example, the 26 nominal definitions that begin '[Definiendum](,) ngulaji jurlpu ...' all define kinds of jurlpu 'birds' (24 species terms and 2 bird life stage terms). Similarly, the 18 definitions that begin '[Definiendum](,) ngulaji watiya ...' overwhelmingly define terms for kinds of watiya 'tree, bush, shrub' (15 species of wooded plant; 2 descriptor or part of wooded plant; 1 artefact made of wood). All such cases are definitions of Warlpiri nominals that are concrete, non-relational, non-descriptive/predicative. As a corollary, nominals that are relational or non-descriptive/predicative or non-concrete or for which there is no obvious genus level superordinate terms are more likely to have definitions that include ngulaji yangka. So,

4 Compare with PPJ's later, parallel definition of the synonym ngapurlu, which appears as example (17) in W\&G and opens Ngapurlu ngula-ji yangka kuja-ka-lu marda-rni karnta-ngku ... 
as relational terms, it is not surprising that 'body part terms' are more likely to include yangka after ngulaji, but, as we see below, they are also more likely to include kujaka after yangka.

The non-occurrence of yangka after ngulaji in the opening of such 'taxonomic' definitions is merely a tendency in PPJ's corpus. For example, there are 15 nominal definitions that open with '[Definiendum](,) ngulaji yangka watiya ...' and 8 of these define species or types of wooded plant, 4 define parts of a wooded plant and 3 define artefacts made from wood. The following examples show parallel openings for definitions of fauna and flora terms without and with yangka.

(5) Rdukurduku-tiri-tiri ngulaji jurlpu wita manangkarra-ngawurpa.... 'Rdukurduku-tiri-tiri are little birds that are found in the open grass lands. ... [PPJ 10/85]'

(6) Lirra-lirra, ngulaji yangka jurlpu wita ngapa-ngawurrpa, ...

'Lirra-lirra is a small water bird ... [PPJ 6/87]'

(7) Ngarlurpu ngulaji watiya wita, ...

'Ngarlurrpu is a small bush ... [PPJ <9/86]'

(8) Pinamparli ngulaji yangka watiya wita ...

'Sturt's Desert Rose is a small bush ... [PPJ <9/86]'

In the above examples, the translations do not show any distinction between definitions with and without yangka. We might propose that those with yangka could instead be rendered as a something like ' $\mathrm{X}$ is that little bird which ...' or ' $\mathrm{X}$ is the small bush which ...'. More literally, examples without yangka might be rendered as 'X, that's a $\mathrm{Y}$ that ...', and those with yangka might be rendered as ' $\mathrm{X}$, that's that $\mathrm{Y}$ which ...' (or, perhaps even ' $\mathrm{X}$, that's the $\mathrm{Y}$ which ...' or 'X, that's that one, a Y which ...'). The critical thing is that the propositional meaning is not different.

\subsubsection{Aside on Arrernte}

It is useful to here compare vernacular definitions by Arrernte native speakers. These often begin '[Definiendum] apele nhenge ...' The first element of the Arrernte opening, the particle apele, is 'commonly used in identifying something or explaining what a word means' and '[s] hows that the speaker wants to make a point of something so that the listener will take special note of it' (Henderson and Dobson 1994: 179). The second element of the opening is the non-spatial demonstrative nhenge. 
This demonstrative overlaps with many of the functions of Warlpiri yangka, including having an 'evocative' function. In describing the use of nhenge as it appears in the definitional opener Henderson and Dobson (1994: 501) write that it:

5a. Introduces some more information about something; (the one) that ..., (those ones) which ..., (the time) when ..., (the place) where ...

Akaperte aheye-aheye apele nhenge akaperte mepepele nhenge atyetele aneme re.

The fontanelle is that (thing) which is in the middle of the head, that (thing) which is soft.

Perlape apele nhenge annge urrperle akweke mape akeme arlekearleke.

Conkerberries are those small dark fruit which you get from a bush.

In definitional openings, Warlpiri yangka could be interpreted as functioning in a way very similar to that described for Arrernte nhenge. As with nhenge, whether yangka is taken to be referring to a person, place, thing, time or event is dependent upon context (in this case, provided by the co-text of the definition). Ennever (pers. comm.) notes a similar formulaic use of the Ngardi recognitional/evocative demonstrative jangu in the openings of vernacular definitions.

\subsubsection{Further properties of PPJ definitions}

Of the 52 vernacular definitions PPJ provided for human and animal body parts, 34 (65 per cent) contain ngulaji yangka and 13 (25 per cent) contain no yangka at all. However, this does not fully represent the relevant opening formula. W\&G neglect the fact that the openings of many definitions, including body part definitions, tend to include the auxiliary complex kuja-ka- 'REL-PRS' after ngulaji, and following yangka if it occurs. In the Warlpiri Dictionary, kuja, the first element of the auxiliary complex, is identified as a 'sentential complementiser' and given the English glossing of 'that, when, where, which, who, what'.

This fuller definitional opener-'[Definiendum](,) ngula-ji yangka kuja$k a$ (-pronominal enclitics) ...'-occurs in 586 (62 per cent) of PPJ's nominal definitions and 555 (96 per cent) of verb definitions. It is this fuller construction that may more closely parallel the Arrernte opener discussed above. It introduces the definitional information that will allow the addressee to identify the unique concept/sense that PPJ is defining. We see ngula as referring to the word form (definiendum), yangka as 
referring to the specific concept associated with the word form and kuja$k a$ - marking a kind of 'relative clause' that introduces the critical elements for narrowing in on that concept. This opening construction basically says 'attend to the following information and you'll know the one I mean'. Close translations of the opener would include 'X, that's that one which ...'; 'that's that thing that'; 'that's that time when'; 'that's that person who'; 'that's that action which'; 'that's the place where'; 'that's the way (it is) when'; etc. (The exact construal is not coded in the opener but is dependent on the following co-text and context.)

Of PPJ's 52 body part definitions, 30 (58 per cent) include kuja-ka (-pronominal enclitics) in the definitional opener, and, of these, 25 (48 per cent) include the full definitional opener '[Definiendum](,) ngula-ji yangka kuja-ka (-pronominal enclitics)'. As noted for yangka, kuja- in definitional openers occurs less in the earliest definitions. Note that the body part definitions of rdaka and lampurnu above don't have kuja- but simply have the auxiliary base $k a$ - in the definitional opener.

Again, the more predicative or relational a nominal is, the more likely a nominal will contain this full opener. More than 50 per cent of PPJ's definitions of kin term nominals contain this full construction, and the vast majority of Warlpiri adjectival nominals contain this construction. Nominals that tend to have a default adjectival function (or a more predicational focus) typically have a stance verb in non-past tense immediately following kuja-ka-ø. In fact, 251 (27 per cent) of PPJ's nominal definitions begin: '[definiendum], ngula=ji yangka kuja-ka-ø stance.verb-NPST ...' ('[definiendum], that=TOP EVOC REL-PRS-3SG.s stance.verb-NPST') and more than 80 per cent of these definitions are of nominals with adjectival function. Thus, the more predicative a nominal is, the more it has the same kind of definitional opener as verbs.

One of PPJ's body part definitions deviates from the standard definitional opening in an instructive way-it substitutes the demonstrative nyampu 'this; here' where the demonstrative yangka would be expected.

(9) Pirlkiri ngula=ji nyampu kuja-ka=rlipa mardarni jimanta-rla kankarlu yapa-ngku manu kardiya-rlu, pirlkiri=ji. [Source: PPJ 6/87]

'Pirlkiri is the upper part of our shoulders, what we have on topboth Aboriginal people and whites. [Literally, Pirlkiri that's this (one) that we all have at the top of our shoulder(s), Aboriginal and white people, that's pirlkiri.]' 
W\&G don't discuss this example, but presumably they don't attribute the 'part' reading to the use of nyampu, which they already include among their Warlpiri exponents of NSM. While 'part' makes sense in the translation, it is merely deducible from the deployment of the demonstrative in context. Here we might expect that PPJ touched the top of his shoulder when dictating the definition. We have no doubt that yangka could sit in place of nyampu in this definition and it would literally mean something like 'Pirlkiri that's that one that we all (inclusive) have at the top of our shoulder(s), Aboriginal and white people, that's pirlkiri. Its construal as a 'part' is part of the mental deictic work which yangka contributes to.

For now, we are working on the assumption that the meaning of the definitional opener that includes yangka is compositional, rather than being an idiomatic construction. Only work with native speakers can fully clarify the situation.

While variations in the typical deployment of definitional openings:

from [Definiendum], ngula $=j i \ldots$;

through [Definiendum], ngula $=j i$ yangka ...;

to [Definiendum], ngula=ji yangka kuja-ka ...

are broadly indicative of a cline from more concrete object concepts through to more relational and predicative concepts, they are not diagnostic of semantic classes at the level of 'body parts' or 'birds'. It is the elements that follow these formulas that get us into the territory of semantic fields.

Looking at PPJ's corpus of vernacular definitions, we undertook an examination of statistically significant collocation relations at the sentence level of all the morphemes which jointly occur in at least 5 definitions, within at least 8 positions in either direction of one another. This allows us to determine any significant patterns of co-occurrence that could be diagnostic of semantic classes. Not surprisingly, given its high frequency, the occurrence of yangka does not significantly predict the occurrence of any other morphemes within the same sentence in PPJ's definitions (not even ngula-ji or kuja-ka-). 
However, there are two significant collocations that are uniquely associated with body part definitions in PPJ's corpus, both involving marda-rni 'haveNPST'. In the first, the elements ka-rlipa 'PRS-IPL.INCL.s' and marda-rni 'have-NPST' occur jointly 27 times ( $k a-r l i p a$ always preceding marda-rni, typically with nothing occurring in between). These 27 co-occurrences appear in 23 different definitions, all of which define body part terms. So, PPJ's use of these two elements together is unambiguously linked to a single semantic class: 'parts that we all (inclusive) have'.

In the second, $k a$-lu 'PRS-3PL.s' and marda-rni 'have-NPST' occur jointly 16 times ( $k a-l u$ always preceding marda-rni, typically with nothing occurring in between). These 16 co-occurrences appear in 15 different definitions, 12 of which are definitions of either gender-specific or animalspecific body part terms — parts that they have.

Recognising the importance of marda-rni 'have' in the Warlpiri definitions of body parts, W\&G (2018: 46) propose two similar exponents of PART for Warlpiri NSM: YANGKA YANGKA MARDARNI 'PART HAVE PARTS'. They argue that mardarni 'to have' 'is one of the formal features which can help distinguish yangka "part" from yangka "that, the one" (2018: 46). However, we take it as instructive that PPJ's earliest definitions of body parts did not use yangka or kuja-, but did use the pronominal clitics -rlipa 'I PL.INCL.SUBj' or -lu '3PL.SUBj' on the auxiliary base $k a$-along with the verb marda-rni 'to have'. He had not fully developed his opening formula, but he had identified his criterial features for the genus-level statement of the class: 'that which we all (inclusive) have' and 'that which they have'. It is these collocations that are truly sui generis for body part terms. Nearly one-third of PPJ's body part definitions that include marda-rni do not include yangka, and since PPJ did not define body parts one after another (unlike W\&G's false suggestion), there is no reason to believe there was any particular local discourse factors that would predict omission.

We can summarise our observations regarding PPJ's dominant pattern for starting definitions for the body part domain in the diagram in Figure 24.1. 
Opening formula:

[Definiendum](,) ngula $=j i$ (yangka) (kuja-) ka-

[Definiendum](,) that=TOP (EVOC) (REL-) AUX.PRS-

Class identifier:

$\mathbf{P}(\ldots)$ marda-rni ...

have-NPST

\begin{tabular}{|c|c|}
\hline \multicolumn{2}{|c|}{ where $\mathbf{P}$ is one of } \\
\hline$=$ rlipa & $=l \mathbf{u}$ \\
\hline$=$ I PL.INCL.SUBJ & $=3$ PL.SUBJ \\
\hline e.g. & \\
\hline palka 'body, torso' & ngurrurnpa 'pubic hair' \\
\hline pirlirrpa 'spirit; life force' & ngirnti ' 1 . tail; 2 . penis' \\
\hline rdaka 'hand' & 'that's (that one) (which) they \\
\hline 'that's (that one) (which) & have' [identifies gender-, age-, \\
\hline $\begin{array}{l}\text { we all have' [identifies parts all } \\
\text { we human beings have] }\end{array}$ & and animal-specific parts] \\
\hline
\end{tabular}

Figure 24.1. Dominant pattern for starting body part definitions in PPJ.

Source: Authors' summary.

The diagram only accounts for the beginning of body part definitions: the definitional opening formula followed by the semantic field identifier. Following this are the statements of differentiae that identify individual parts. These may include specifying particular possessors, localising the part with respect to other parts, identifying the function of the part and/ or quantifying and describing the size of the part. Our main purpose, however, has been to show that W\&G's claims regarding yangka (more specifically ngulaji yangka) do not hold for the extensive corpus of PPJ's vernacular definitions. Our claim, therefore, is that PPJ does not use anything that immediately translates as 'part'; instead he makes a possession statement using ka-rlipa or ka-lu with mardarni 'have' which, along with specific spatial location and/or function statements, define referents in the so-called 'body part' domain. More precisely, PPJ uses mardarni to indicate the possessive relation between humans and/or animals and any of their immediate subparts.

\subsection{Flaw when comparing definitions across semantic domains}

W\&G (2018: 46, note 9) do recognise that definitions have been contributed by Warlpiri people other than PPJ: 
Since so many of the vernacular definitions originate with PPJ, it is possible that other Warlpiri speakers may have alternative definitional strategies, or different preferences so far as the balance between the two yangka constructions described in Sections 6 and 7 are concerned.

W\&G could have applied this cautionary note later when considering how the use of yangka in definitions varies across semantic domains:

the sequence ngulaji yangka is not widely used in the definitions of nouns of all kinds. When we inspected 50 randomly selected entries in the Warlpiri Dictionary's 'fauna domain' we found that only two of them used ngulaji yangka. Of these, one was clearly used in the sense of 'like' and the other in the sense of 'that, the one'. By contrast, in our collection of 64 body-part entries as many as 19 include the sequence ngulaji yangka, with yangka almost always indicating a particular part of the body. A similar sampling exercise with words from the 'manufacture domain' produced parallel results, i.e. in most of these definitions an opening yangka had the sense either of 'like (when)' or 'that, the one'. (W\&G 2018: 48)

The correlation is more with PPJ as definition author: definitions in the fauna and manufacture domains were mostly created by other Warlpiri speakers. Hence we disagree with W\&G's (2018: 49) inference that

while the sequence ngulaji yangka can indeed be found in many parts of the Warlpiri Dictionary, its use in the definitions of bodyparts is sui generis, and supports the hypothesis of 'part' as a distinct meaning of yangka.

As shown above (section 2.2), the sequence ngulaji yangka is part of an opening definitional formula heavily favoured by PPJ and its use in body part definitions is not sui generis.

In the version of the dictionary consulted by W\&G, there are 385 entries in the 'Fauna: kuyu' domain. Of these, 205 entries contain one or more vernacular definitions which define a species or kind (of 'fleshy fauna'). Of these 205, PPJ provides vernacular definitions for 46 (22 per cent), a much smaller proportion than in the domain of body parts, and his definitions all begin, '[Definiendum], ngulaji ...' and 9 of these include yangka after ngulaji. That is, 20 per cent of PPJ's fauna definitions begin '[Definiendum], ngulaji yangka ...'. Only one other definition of a species or kind in this domain contains ngulaji yangka [yilyinkarri, HN0279]. Only two further vernacular definitions for species or kind in this domain 
contain ngulaju yangka, unsourced. So, of definitions not sourced to PPJ, only about 2 per cent contain ngulaji yangka or ngulaju yangka. Thus, while PPJ does (for reasons explained) use ngulaji yangka less in vernacular definitions for 'Fauna: kuyu', he still uses it much more than the other contributors to the domain. W\&G's methodological error in their fauna study was to not distinguish PPJ's definitions and to presume that other definers use the same locution. In non-PPJ fauna definitions, the most common opener includes karnalu ngarrirni (PRS-I PL.EXCL.SBJ tell-NPAST 'we call it') (49 examples, with the most common being '[Definiendum], karnalu ngarrirni ...').

Another misapprehension is about the order in which PPJ chose words to define:

The word palka 'body' occurs in some definitions, but it is mostly omitted since the indigenous lexicographer is, presumably, composing several definitions one after another so it is understood that the context is about parts of the body. (W\&G 2018: 46)

Actually, PPJ usually proceeded with groups of phonologically similar words, often from alphabetical lists of words beginning with a particular sound; and even when defining words from the same semantic domain he would repeat the parts of the definition in common, so that each definition could stand alone.

\subsection{Spurious correlation}

As Wierzbicka (2008) has observed, the concept colour is not lexicalised in Warlpiri. Inspection of the vernacular definitions of particular Warlpiri colour terms often include yangka, and their English translation of the definition uses the word colour, as in these examples:

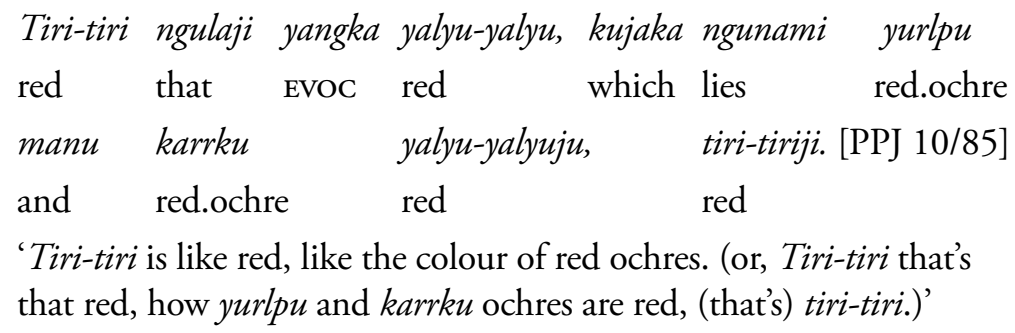


and

(11)

Puyurr-puyurrpa, ngulaji yangka kujaka nyinami warna grey that Evoc which sits snake kunjuru-kunjuru, yangka kunjuru-piya. [PPJ 6/87] smoke-smoke(grey) Evoc smoke-like 'Puyurr-puyurrpa is like a grey snake, one that is (coloured) like smoke.'

By a reasoning parallel to that used by $\mathrm{W} \& \mathrm{G}$ to infer that yangka has a sense PART, one could also infer that yangka has a sense COLOUR. Instead W\&G (2018: 41-43) use such examples to claim that yangka has yet another sense, 'like', and so take yangka to also be a Warlpiri exponent of NSM's prime LIKE.

\subsection{Poor fit with NSM theory}

The NSM framework includes these standard combinatorial possibilities of PART: ${ }^{5}$

part of someone's body; this part, the same part, another part, this other part; this something has two/many parts

Apart from the first of these, W\&G do not show how yangka could be used to express these phrases. If they had been right about yangka, then it would only have been in one context of use, and until a demonstration is made about the exponents (allolexes) that are used for the other combinatorial contexts, Warlpiri stands as a language for which the NSM equivalent of PART - HAVE PARTS is to be discovered. One allolex in one context does not make an NSM prime.

The wide range in Warlpiri of contextual translation equivalents for the PART meaning is to be measured against NSM's Strong Lexicalization Hypothesis (Goddard 1994a: 13), which has from its inception been compromised in its application by allolexy and purported polysemy.

5 Chart of NSM semantic primes, version 19 (12 April 2017). Available at: intranet.secure.griffith. edu.au/_data/assets/pdf_file/0019/346033/NSM_Chart_ENGLISH_v19_April_12_2017_ Greyscale.pdf. 
W\&G postulate polysemy of yangka in particular to meet the requirement for lexical expression of PART. We prefer the monosemic bias (until forced to polysemy), following Ruhl (1989), and indeed another NSM tradition:

One assumes to begin with that there is but a single meaning, and attempts to state it in a clear and predictive fashion, in the form of a translatable reductive paraphrase. Only if persistent efforts to do this fail is polysemy posited. (Goddard 2000: 132)

\section{Other difficulties for W\&G's account}

This section describes some hurdles for W\&G's account; these are not complete obstacles, but rather are considerations which should give pause.

First, it is significant that a PART sense has remained unnoticed by lexicographers and translators. No Warlpiri wordlist or dictionary has associated yangka with a sense of PART, including the two lexicons compiled independently of the main dictionary used by W\&G. ${ }^{6}$ Further, yangka has not been used to express PART in published translations (see section 5).

Next, consider the equivalent of yangka in related languages. Ennever (2018: 177) discusses recognitional/evocative demonstrative jangu (and yangka) in Ngardi, a western neighbour of Warlpiri. McConvell (2006: $112,117)$ mentioned Warlpiri yangka in his comparative discussion of demonstratives as complementisers. He pointed out parallels in other central Australian languages: Arrernte nhenge (Henderson and Dobson 1994) and Pitjantjatjara/Yankunytjatjara panya (Goddard 1996: 124-25); ${ }^{7}$ there is also Anmatyerr nheng (Green 2010: 447-48) and Kaytetye wenhe (Turpin and Ross 2011: 633). Their detailed dictionary entries of these equivalents

6 The Swartz lexicon (available at: ausil.org/Dictionary/Warlpiri/lexicon/index.htm) has yangka 'aforementioned one, same one mentioned before'; Reece (1975) has yangkari 'another time, another, other one', yangkakurra 'to the same place'.

7 '1. that, "you know the one". Calls the listener's attention to the fact that he or she is already familiar with the thing being referred to (generally something not explicitly referred to so far) ... 2 . Used as an introductory particle to present the following clause as an explanatory comment; can often be translated as "because" ... 3. Used as a hesitation particle while groping for something to say'; and Goddard (1983; quoted by Himmelmann 1996): 'It is not usually used about things which are fully topical - ie already being talked about, but rather to re-introduce something into the conversation ... Actually, panya ANAPH does not presuppose an explicit mention in previous discourse, but simply that the addressee be able to call to mind the intended referent'. 
give no hint of a PART sense, nor a plausible bridging context that would semantically link PART and a non-spatial recognitional demonstrative sense. McConvell (2006: 116) observed a parallel with Walmajarri yangka:

GMSCs [general modifying subordinate clauses] appear to be formed mainly with the complementizers yangka in Eastern Walmajarri and with yangkakaji in other dialects. Yangka is also a demonstrative which is both evocative and anaphoric - that one known to both speaker and hearer or previously referred to' and the related complementizer also retains at least part of that meaning according to the Walmajarri dictionary- 'when (something we both know about happens)' (Richards \& Hudson 1990: 307).... The meaning of the demonstrative yangka is similar to Nash's 'evocative' and Himmelmann's 'recognitional' previously referred to.

More broadly, consider that a lexical gap for PART has been noted in some other languages. Generally, Enfield et al. (2006) observe that an equivalent to PART was not immediately available in several of the 10 languages they examined, and that instead various kinds of possession and location constructions were used in place of partonomy statements. Significantly, in Casagrande and Hale's (1967) seminal work on Papago folk definitions, not one of the 800 definitions specifically encoded a part-whole relation and the authors merely suggested it as a potential semantic relation despite its absence from their data.

W\&G cite two languages that seem at first to lack a word with the sense PART, but in which, on a closer look, PART has been found as a sense of a word with other senses. First, Goddard (1994b: 255-56) discerned HAVE PARTS as a sense of the Yankunytjatjara nominal suffix -tjara 'having' ${ }^{8}$ (and made no suggestion of the panya mentioned above). Second, W\&G (2018: 50-51) claim a precedent in the Papuan language Koromu, citing Priestley (2017):

8 Goddard (1994b: 256) associates the suffix with the nominal stem tjara, which he also glosses as 'part (of)', but it is not clear that tjara has the sense PART required to be an exponent of the NSM prime. The entries in his dictionary (Goddard 1992: 147) have the stem tjara with a somewhat different meaning 'divided, apart, spatially separated'. In Pintupi/Luritja, another dialect of the Western Desert Language, Hansen and Hansen (1991: 141) define tjarra as 'forked stick; divided; the fork where branches protrude from the trunk or other branches', and the combination tjarra kutjupa "branch; another subject; lit. "another fork"; can be used literally to refer to the fork of a tree branch or creek tributary; can be used figuratively of a change in subject matter under discussion'. 
What is particularly interesting in the present context is that one of the main exponents of PART in Koromu is a demonstrative, somewhat like the situation in Warlpiri. (W\&G 2018: 51)

We would agree with the parallel with Warlpiri, but for a different reason: in our view the demonstrative does not have a second sense but rather it can function pragmatically to convey the PART concept. Note that earlier, Priestley $(2008: 173,149)$ had described the demonstrative mo 'this/here' and the quantifier asao 'some (some others) [also 'part']' without polysemy.

\section{The meaning of yangka}

Warlpiri yangka has been taken to be a recognitional demonstrative, of the type described by Himmelmann (1996: 230), though as we elaborate below, this does not capture the range of uses. Yangka, the most common word in the Warlpiri corpus, mostly occurs absolutely; the next most common occurrence is with some enclitic (notably focal $-j u$ ) or suffix, and there are relatively few occurrences with a nominal suffix. It seems that (absolute) yangka can be omitted from (most?) utterances without a change in the 'coded' or 'propositional' meaning, as exemplified in section 2.2.1. Also, note the various paradigmatic/non-co-occurring sets that involve yangka: it rarely occurs in the same noun phrase as nyampu 'this', yali 'that', or other demonstratives (see example (9), in section 2.2.3).

The recognitional component of the meaning of yangka is well-suited for use in interaction. However, yangka is also not uncommon in written Warlpiri, as witness its occurrence in nearly a hundred of the Warlpiri booklets in the Living Archive of Aboriginal Languages (LAAL). ${ }^{9}$ Here is one example in the middle of a written story (Napaljarri and Jakamarra 1976: 5):

\begin{tabular}{|c|c|c|c|}
\hline $\begin{array}{l}\text { (12a) Yuka-ja } \\
\text { enter-PST }\end{array}$ & $\begin{array}{l}\text { karnta } \\
\text { woman }\end{array}$ & $\begin{array}{l}\text { yangka }=j u \\
\mathrm{EVOC}=\mathrm{TOP}\end{array}$ & $\begin{array}{l}\text { janganpa-jangka }=j u . \\
\text { possum-from }=\text { TOP }\end{array}$ \\
\hline $\begin{array}{l}\text { 2b) Karnta } \\
\text { woman }\end{array}$ & $\begin{array}{l}\text { nyanungu=ju } \\
\text { he/she/it=TOP }\end{array}$ & $\begin{array}{l}\text { yuntard } \\
\text { beautifi }\end{array}$ & $\begin{array}{l}\text { yirni. } \\
\text { y }\end{array}$ \\
\hline
\end{tabular}

9 Available at: laal.cdu.edu.au/search/?q=all:yangka\&f]]=language:450808\&o=dd\&amp;mode=. 
The first sentence refers to a woman who has been mentioned in preceding sentences. In (12b), the referent of yangka is taken up (after a direct speech clause) by the determiner nyanungu, pronominally definite and translated by 'the'.

In interactional contexts, yangka could colloquially be glossed 'you know', as when the speaker is searching for a word or talking about something for which there is not an easy expression. Bromhead (2009: 217-19) shows how this English expression has arisen in the last few centuries. The meaning of the English near-equivalent you-know-WHAT has been explicated by Enfield (2003: 107) as: ${ }^{10}$

\section{YOu-knOw-WHAT}

\section{something}

I don't want to say the word for this thing now

I don't say it now because I know I don't have to

by saying you-know-wHAT I think you'll know what I'm thinking of

An explication of Warlpiri yangka can be based on the last line of Enfield's explication. We can allow that, depending on further contextualising information, the concept that would be called up by yangka could be PART, with the conceptual primitive nevertheless still not lexicalised. There is a close equivalence also with Cutfield's (2012: 383) analysis of Dalabon kanh: 'what the speaker is appealing to is not a prior mention or shared knowledge per se, but the addressee's deductive capacity ... the speaker is not merely saying "you know what I'm talking about", but rather "you can work out what I'm talking about".'

\section{Expressing 'part' in Warlpiri}

Warlpiri has various ways of expressing the PART concept or translating English part (of), including: the part-whole construction (Hale 1981), the use of coverb quantifier puta 'incompletely' and nominals such as

10 Note the Lao near-equivalent (Enfield 2003: 110) shares with Warlpiri yangka the possible lack of an expression for the relevant notion:

qan0-nan 4 'that thing'

something (happens/is the case)

I don't know how to say what I'm thinking of

by saying qan0-nan4 ('that thing') I think you'll know what I'm thinking of 
ngalya-kari (which W\&G 2018: 21 mention in relation to SOME), and in some contexts rdilyki-kari 'a broken-off bit', or larrakari 'piece, split off bit' ('part, half', Reece 1979: 120). The verb marda-rni 'to have, hold' has a wide range, which can translate 'have as a part' and many other concepts, but not as a distinguishable sense as far as we can discern (see section 2.2.3 and footnote 11). And, as for Yankunytjatjara -tjara, it would have to be demonstrated as a polysemous sense of the form, since expressions for 'with' (comitatives) could be proposed to have HAVE PARTS as a sense, although, (for example) a person with brothers or sisters is 'with something' but a sibling is not a part of a person. Nash (2014: 84-85) discusses part and side in defining certain Warlpiri kinship meanings.

It is instructive to consider how English part has been translated into Warlpiri. Several substantial texts have been translated into Warlpiri in collaboration with trained Warlpiri translators. The largest of these is the Warlpiri Bible, two key passages of which are presented in Appendix 24.2, to which the reader is referred for the circumlocutions around part, and also the absence of yangka as its translation. Two other translations we have checked are that of the short children's novel Storm Boy (Thiele 1963) and of a manual on troubleshooting ignition systems (Granites and Shopen 1987). The former has no instance of part but has a few instances of bit in a sense like PART. The only one clearly translated is

(13) It had a dirt floor, two blurry bits of glass for windows (Kindle Location 31)

Kaninjarniji kala ngunaja walyajuku kanunjuju purluwu-wangu. Wintawu-kuju ngulaju kirlajijarra 'Inside there was no floor just dirt on the bottom. For windows two bits of glass' (our back-translation)

The addition of -jarra 'two' on kirlaji 'glass' favours the countable entity reading, whereas the unmarked sense of Warlpiri nouns covers mass or property readings, consistent with their ability to be predicates as well as forming individual referring expressions. ${ }^{11}$

11 We thank Mary Laughren for helpful discussion of this point. 
The English original of the troubleshooting manual has several instances of part, as one would expect in instructions about mechanisms. A couple do show a potential translation equivalent of part, notably jintakari jintakari 'one by one' construed with the plural pronominal enclitic =jana object of mardarni 'have' in: ${ }^{12}$

(14) 24. The primary circuit has the following parts, starting with the battery:

$\begin{array}{clll}\text { 24. Wirlinyi } & \text { parnka-ngu } & \text { jinta-ngku } & k a=j a n a \\ \text { 24. day.trip } & \text { run-NOMIC } & \text { one-ERG } & \text { AUX.PRS=3.PL.OBJ } \\ \text { marda-rni } & \text { jinta-kari } & \text { jinta-kari, } & \text { pirilyi-ngirli: } \\ \text { have-NPST } & \text { one-other } & \text { one-other } & \text { charcoal-from }\end{array}$

\section{Conclusion}

W\&G went looking for 'part' quite literally, presuming that the uses of the English word part in translations of Warlpiri sentences in the Warlpiri Dictionary would yield a Warlpiri counterpart of the NSM prime PART. They thought they had found it in the form of the demonstrative yangka, used primarily in the vernacular definitions of the native Warlpiri lexicographer, Paddy Patrick Jangala. We have shown that a close look at PPJ's definitions and definitional style doesn't support their hypothesis. Keeping to a monosemic bias (until forced to polysemy), we argue that uses of yangka in definitions is consistent with its use as a demonstrative elsewhere-directing the addressee to use context and co-text to bring the speaker's intended referent to mind. In section 4, we suggested directions an NSM-style definition of yangka might take, indicating that a 'part' interpretation is a consistent pragmatic deduction by the addressee in certain contexts, but is not what yangka is coding. However, we also

12 This use of mardarni 'have' to predicate an entity's possession of an inherent corporeal or noncorporeal part also occurs in definitions of terms for birds and for meat animals and elsewhere. In fact, more than half of the 91 occurrences of mardarni across PPJ's 943 nominal definitions are in this function, despite it being listed as the fifth, and last, sense of the verb in the Warlpiri Dictionary. Though still glossing this function as 'have', the dictionary states for this sense: 'Definition: $\mathrm{Y}$ is part of X'. However, it appears that X can only be a term for the complete being of which $\mathrm{Y}$ is a part, it cannot itself be a part. This is consistent with the dictionary's example sentences for this sense. It is not that mardarni 'have' is the Warlpiri reflex of PART; possession is clearly the relevant notion. 
identified the more widespread and consistent resources Warlpiri speakers use when discussing part-relations. In the process, we hope we have helped NSM refine some of its methodological assumptions and approaches.

\section{Acknowledgements}

We have benefited from discussion of the topic with Mary Laughren, and the comments of two reviewers.

\section{References}

Australian Society for Indigenous Languages (2001). The Bible in Walpiri. Available at: aboriginalbibles.org.au/Warlpiri/.

Bromhead, Helen (2009). The Reign of Truth and Faith: Epistemic Expressions in 16th and 17th Century English. Berlin: Mouton de Gruyter. doi.org/10.1515/ 9783110216028.

Casagrande, Joseph P. and Kenneth L. Hale (1967). Semantic relationships in Papago folk definitions. In Dell H. Hymes and William E. Bittle (eds), Studies in Southwestern Ethnolinguistics. The Hague: Mouton, 165-93.

Cutfield, Sarah (2012). Demonstratives in Dalabon: A Language of Southwestern Arnhem Land. Unpublished PhD dissertation, Monash University. Available at: hdl.handle.net/11858/00-001M-0000-0013-AAB9-A.

Enfield, Nick J. (2003). The definition of what-d'you-call-it: Semantics and pragmatics of recognitional deixis. Journal of Pragmatics 35 (1): 101-17. doi.org/10.1016/S0378-2166(02)00066-8.

Enfield, N.J., Asifa Majid and Miriam van Staden (2006). Cross-linguistic categorisation of the body: Introduction. Language Sciences 28 (2-3): 137-47. doi.org/10.1016/j.langsci.2005.11.001.

Ennever, Tom (2018). Nominal and Pronominal Morphology of Ngardi: A Ngumpin-Yapa Language of Western Australia. Unpublished MPhil thesis, University of Queensland. doi.org/10.14264/uql.2018.560.

Goddard, Cliff (1983). A Semantically-Oriented Grammar of the Yankunytjatjara Dialect of the Western Desert Language. Unpublished PhD dissertation, The Australian National University. Available at: hdl.handle. net/1885/132711. 
Goddard, Cliff (1992). Pitjantjatjara/Yankunytjatjara to English Dictionary. Alice Springs: IAD Press.

Goddard, Cliff (1994a). Semantic theory and semantic universals. In Cliff Goddard and Anna Wierzbicka (eds), Semantic and Lexical Universals: Theory and Empirical Findings. Amsterdam: John Benjamins, 7-30.

Goddard, Cliff (1994b). Lexical primitives in Yankunytjatjara. In Cliff Goddard and Anna Wierzbicka (eds), Semantic and Lexical Universals: Theory and Empirical Findings. Amsterdam: John Benjamins, 229-62. doi.org/10.1075/ slcs.25.13god.

Goddard, Cliff (1996). Pitjantjatjara/Yankunytjatjara to English Dictionary (revised 2nd edn). Alice Springs: IAD Press.

Goddard, Cliff (2000). Polysemy: A problem of definition. In Yael Ravin and Claudia Leacock (eds), Polysemy: Theoretical and Computational Approaches. Oxford: Oxford University Press, 129-51.

Granites, Kurt Japanangka and Tim Shopen (trans.) (1987). Jitirninjakurlangupinki pina-jarrinjakurlangu. Lajamanu [Simple Method of Locating Faults in the Ignition System: Sections 1-34]. Lajamanu: Vocational Training Branch, International Labour Office. Available at: laal.cdu.edu.au/record/cdu:59936/info/.

Green, Jennifer Anne (2010). Central \& Eastern Anmatyerr to English dictionary. Alice Springs: IAD Press.

Hale, Ken (1981). Preliminary remarks on the grammar of part-whole relations in Warlpiri. In Jim Hollyman and Andrew Pawley (eds), Studies in Pacific Languages and Cultures in Honour of Bruce Biggs. Auckland: Linguistic Society of New Zealand, 333-44.

Hale, Kenneth L. (1966-67). [Warlpiri transcripts]. AIATSIS Library, call number MS 3171, etc.

Hansen, Kenneth C. and Lesley E. Hansen (1991). Pintupi/Luritja Dictionary (3rd edn). Alice Springs: IAD Press.

Henderson, John Keith and Veronica Dobson (1994). Eastern and Central Arrernte to English Dictionary. Alice Springs: IAD Press.

Himmelmann, Nikolaus P. (1996). Demonstratives in narrative discourse: A taxonomy of universal uses. In Barbara A. Fox (ed.), Studies in Anaphora. Amsterdam: John Benjamins, 205-54. doi.org/10.1075/tsl.33.08him. 
McConvell, Patrick (2006). Grammaticalization of demonstratives as subordinate complementizers in Ngumpin-Yapa. Australian Journal of Linguistics 26 (1): 107-37. doi.org/10.1080/07268600500531669.

Napaljarri, Tess and J. Jakamarra (1976). Yarlpurru-rlangu-kurlu. Yuendumu, Northern Territory: Bilingual Resource Development Unit. Available at: laal. cdu.edu.au/record/cdu:36461/info/.

Nash, David (2014). Alternating generations again again: A response to Wierzbicka on generation moieties. In Lauren Gawne and Jill Vaughan (eds), Selected Papers from the 44th Conference of the Australian Linguistic Society (2013). Melbourne: University of Melbourne, 77-101. Available at: hdl.handle.net/11343/40958.

Priestley, Carol (2008). A Grammar of Koromu (Kesawai): A Trans New Guinea Language of Papua New Guinea. Unpublished PhD dissertation, The Australian National University. Available at: hdl.handle.net/1885/150382.

Priestley, Carol (2017). Some key body parts and polysemy: A case study from Koromu (Kesawai). In Zhengdao Ye (ed.), The Semantics of Nouns. Oxford: Oxford University Press, 147-79. doi.org/10.1093/oso/978019873 6721.003 .0006 .

Reece, Laurie (1975). Dictionary of the Wailbri (Walpiri) Language of Central Australia. Part I: Wailbri-English. (Oceania Linguistic Monographs 19). Sydney: University of Sydney.

Reece, Laurie (1979). Dictionary of the Wailbri (Walpiri) Language of Central Australia. Part II: English-Wailbri. (Oceania Linguistic Monographs 22). Sydney: University of Sydney.

Ruhl, Charles (1989). On Monosemy: A Study in Linguistic Semantics. New York: SUNY Press.

Thiele, Colin (1963). Storm Boy. London: New Holland.

Turpin, Myfany and Alison Ross (2011). Kaytetye to English Dictionary. Alice Springs: IAD Press.

Wierzbicka, Anna (1972). Semantic Primitives. Frankfurt: Athenäum.

Wierzbicka, Anna (2008). Why there are no 'colour universals' in language and thought. Journal of the Royal Anthropological Institute 14 (2): 407-25. doi.org/10.1111/j.1467-9655.2008.00509.x

Wierzbicka, Anna and Cliff Goddard (2018). Talking about our bodies and their parts in Warlpiri. Australian Journal of Linguistics 38 (1): 31-62. doi.org/ 10.1080/07268602.2018.1393862. 
Wilkins, David P. (2000). Ants, ancestors and medicine: A semantic and pragmatic account of classifier constructions in Arrernte (Central Australia). In Gunter Senft (ed.), Systems of Nominal Classification. Vol. 4: Language, Culture and Cognition. Cambridge: Cambridge University Press, 147-216.

\section{Appendix 24.1}

The source of W\&G's example in (1), equivalent to our (2), derives from Hale (1966-67: 0215) in a 'Check on Lander River vocabulary vis à vis Yurntumu'; field tape 2.32, 1:00:57 to 1:01:29 of AIATSIS (Australian Institute of Aboriginal and Torres Strait Islander Studies) archive recording Hale_K01 499A. The corresponding audio excerpt (SJJ-kantumu.wav) is available at: cloudstor.aarnet.edu.au/plus/s/BemyHVBPfXvuwk3/ download. The speaker, Sam Johnson Japangardi, has used kantumu in the immediately preceding part of the interview (defining palkarni 'scarce, last supplies of, precious, indispensable'), in this context:

Kuyu yalumpu-wanarri jinta, ngulalu panungku muurlpa pajika_palkarni. Yapangka panungka yangka. Panupuru yapapuru. Kultu kajilpajana panukariki yungkarla, manu yangka wanarrikari jintakari, o jurrurlangu, ngurljurlangu, manu kantumu, yardipi yangka kantumu karlipa ngarrini, muurlparlulu nganja palkarni. Panukurnajana muku-yungu, kala yalumpu wanarri jinta, ngulalu nyurrurlapaturlu palkarni nganja. Wiyarparlu. Jintajuku. Jipirri yangka panungku. Ngulajuku.

'That meat-one upper leg, you lot cut it carefully-it's the last one. That's for many people. (Shared) among many people. He would give the ribs to many others, and that other upper leg, or the head for example, the ribs too, and the rump, the hip we call kantumu, you lot eat the last one carefully. I gave it to all of them, but that one upper leg, you lot eat that one, it's the last. Poor things. Just one. Many (people) jointly. That's it.'

Sam continues his explanation of kantumu:

Jirrimaja. Kala yapa yardipi, ngulaji yardipi. Yarlipiri. Jirrima. Karlipanyanu ngarrini jirrimayijala. Yardipi, yarlipiri. Ngulajuku.

'We have two names for it. As for people, it (hip) is (called) yardipi or yarlipiri. We call that part of ourselves by two names as well: yardipi and yarlipiri.' (translation in dictionary) 


\section{Appendix 24.2. 'PART' in the Warlpiri Bible}

There are two passages in the Warlpiri Bible where the concept of PART is central to the message. Consider how the Warlpiri Bible translation expresses these two passages (Matthew 5:28-30 and 1 Corinthians 12:1227; from The Bible in Warlpiri, with our back-translation). ${ }^{13}$ In short, there is no particular lexeme expressing the notion of BODY PART, but rather it is evoked in context by listing a few. Yangka doesn't appear in these Warlpiri translations, but the comitative -kurlu and the verb mardarni variously predicate the relation between the body and its parts (and the privative is used to predicate part absence).

\section{Matthew 5:28}

(King James version) But I say unto you, That whosoever looketh on a woman to lust after her hath committed adultery with her already in his heart. 29. And if thy right eye offend thee, pluck it out, and cast it from thee: for it is profitable for thee that one of thy members should perish, and not that thy whole body should be cast into hell. 30. And if thy right hand offend thee, cut if off, and cast it from thee: for it is profitable for thee that one of thy members should perish, and not that thy whole body should be cast into hell. ${ }^{14}$

29 Yuwayi, ngaka kajikanpa marda karnta-kari lirlki-nyanyi milpajarrarlu. Kuja-kujakuju-nyanu milpa-jarra wilypi-manta jurnta, kajikangku Kaaturlu kijirni milpa-jarra-kurlu-juku warlu wiri-kirra kuja-ka jankami tarnnga-juku.

Yes, if you might look lustfully at another woman with both eyes. To avoid that, pluck away your eyes, or God will throw you still with both eyes into the big fire which burns forever.

13 The Walpiri Bible is a project of the Australian Society for Indigenous Languages (2001), available at: aboriginalbibles.org.au/Warlpiri/.

14 Matthew 5:28 available at: ebible.org/study/?w1=bible\&t1=local:wbp\&v1=JN1_1. 
30 Ngaka kajikanpa marda majungka-jarrimi, kajikanpa marda nyiyarlangu purungku-mani rdaka-jarrarlu. Kuja-kujakujunyanu rdaka-jarra mururl-pajika jurnta, kajikangku Kaaturlu kijirni rdaka-jarra-kurlu-juku warlu wiri-kirra kuja-ka jankami tarnnga-juku.

Yes, if you might do bad, you might steal something with both hands. To avoid that, chop off both hands, or God will throw you still with both hands into the big fire which burns forever.

Kajilpangku Kaaturlu kijikarla nguru yali-kirra palka wanapi-jiki, ngulaju maju-nyayirni nyuntukuju. Kala kajinpa yukamirra Kaatu-kurlangu-kurra nguru-nyayirni-wangu-kurra rdaka-jarra-wangu manu marda milpa-jarra-wangu, ngulaju ngulajuku. Kapunpa nyanungu-kurlu nyina tarnnga-juku.

If God were to throw your whole body into that region, that is very bad for you. But when you enter God's special area without both hands and maybe without both eyes, then alright. You will be with him forever.

\section{Corinthians 12:12-27}

(King James version) 12 For as the body is one and has many members, but all the members of that one body, being many, are one body, so also is Christ. ... 14 For the body is not one member but many. 15 If the foot should say, 'Because I am not hand, I am not of the body,' is it therefore not of the body? ... 18 But now hath God set the members every one of them in the body, as it hath pleased him ... 23 And those members of the body, which we think to be less honourable, upon these we bestow more abundant honour; and our uncomely parts have more abundant comeliness. 24 For our comely parts have no need: but God hath tempered the body together, having given more abundant honour to that part which lacked: $:^{15}$

15 Available at: ebible.org/study/?w1=bible\&t1=local:wbp\&v1=JN1_1. 


\begin{tabular}{|c|c|c|c|c|c|}
\hline $\begin{array}{l}\text { Yapa- } \\
\text { kurlangu-rlu }\end{array}$ & $\begin{array}{l}\text { palka- } \\
\text { ngku }\end{array}$ & $k a$ & marda-rni & jurru & rdaka-jarra, \\
\hline $\begin{array}{l}\text { person-POss- } \\
\text { ERG }\end{array}$ & $\begin{array}{l}\text { body- } \\
\text { ERG }\end{array}$ & AUX.PRS $\mathrm{h}$ & have-NPST & head & hand-Du \\
\hline $\begin{array}{l}\text { ERG } \\
\text { wirliya-jarra }\end{array}$ & manu & panu- & Panu=juku & $k a-l u$ & jinta-jarri-mi \\
\hline foot-DU & and & $\begin{array}{l}\text { kari. } \\
\text { many- } \\
\text { other }\end{array}$ & many=still & $\begin{array}{l}\text { AUX.PRS- } \\
\text { they }\end{array}$ & $\begin{array}{l}\text { one-become- } \\
\text { NPST }\end{array}$ \\
\hline yapa-ngka & $\begin{array}{l}\text { palka- } \\
\text { ngka }\end{array}$ & $\begin{array}{l}\text { jinta- } \\
n g k a=j u k u\end{array}$ & \multicolumn{2}{|c|}{ Ngula-piya-yijala } & Jesus Christ $=j i$ \\
\hline person-LOC & $\begin{array}{l}\text { body- } \\
\text { LOC }\end{array}$ & $\begin{array}{l}\text { one- } \\
\text { LOC=still }\end{array}$ & \multicolumn{2}{|c|}{ that-like-too } & $\mathrm{JC}=\mathrm{TOP}$ \\
\hline manu & ngalipa & yapa & \multirow{2}{*}{\multicolumn{2}{|c|}{$\begin{array}{l}\text { nyanungu-nyangu. } \\
\text { he-poss }\end{array}$}} & \\
\hline and & $\begin{array}{l}1 . P L . \\
\text { INCL }\end{array}$ & person & & & \\
\hline
\end{tabular}

Literally: 'A person's body has a head, two hands, two feet and many other (things). While they are many they are one in a person's one body. So like that too is Jesus Christ and we his people.' (our interlinearisation and back-translation)

14 Yapa-kurlangurlu palkangku-ka mardarni jurru, rdaka-jarra, wirliyajarra manu panu-kari. Panu-juku kalu jinta-jarrimi yapangka palkangka jintangka-juku.

Literally: 'A person's body has a head, two hands, two feet and many others. The many are united in a person's single body.'

18 God-rlu-ngalpa palka kardu-manu jurru-kurlu, rdaka-jarra-kurlu, wirliya-jarra-kurlu manu panu-kari-kirli, ngulaku-ngarntiji kamparrujuku jirringi-yirrarnu-wiyi nyarrparlu yungu-ngalpa jinta-maninjarla yirrarni palkangka jintangka ngalipa-nyangurla jurru, rdaka-jarra, wirliya-jarra manu panu-karirlangu.

Literally: 'God made our body(/bodies) with a head, with two hands/ arms, with two feet and with many others, ready for that he first decided how, having made us one, to put us in our one body a head, two hands/arms, two feet and many others too.' 
23 Yapangku marda kajika manngu-nyanyi pinti ngulaju nganta nyirntinyirnti nganta. Kujarlaju kajika-nyanu maparni jarangku karalypa-kardalku. Manu kajika-nyanu marda ngarntapiri nyanjarla kurntaku ngurrju-mani. Ngula-kujaku kanyanu parnta-yirrarni wawarda kurntangka yapa-patu-kari-kijakurlangu. 24 Yinngirri manu jurru wakurlu, ngulaju marda kajika-nyanu miimii-nyanyi yuntardi nganta. Kujarlaju, kula kanyanu parnta-yirrarni. Jijaji Kiraji-kirlangu yapa, ngulaju karlipa nyina turnu jintangka-juku. Kujarlaju kajilpanyanu nganangku-puka Kirijinirli ngurrju-pajikarla Kirijini-karipiya-wangu nganta, ngulaju jarrwara-nyayirni! Kaaturlu kangalpa turnu-maninjarla jinta-kurra-mani, ngula-jangkarluju yungurlipa-jana warrawarra-kanyi Kirijini-kariyi-nyanu yangka rampaku.

Literally: 23 'A person might perceive skin as rough. So he might rub himself smooth with fat. And on seeing his groin he might perhaps make himself ashamed. To avoid that he covers himself with clothes out of shame so that others can't (see it) either.' 24 'His face and head hair, he might take a long look at thinking how good-looking he is. So he doesn't cover (that part of) himself. Jesus Christ's people, we are together in one. Thus whatever Christian calls himself "good" thinking he's not like other Christians, that is very wrong! God gathers and unites us, so that we look after other Christians - those weak (ones).' 
This text is taken from Meaning, Life and Culture: In conversation with Anna Wierzbicka, edited by Helen Bromhead and Zhengdao Ye, published 2020 by ANU Press, The Australian National University,

Canberra, Australia.

doi.org/10.22459/MLC.2020.24 